\title{
Formulating Standards for Awards of Punitive Damages in the Borderland of Contract and Tort
}

Under the American rule, punitive damages nuay not be recovered in actions arising out of contract. ${ }^{1}$ Punitive daniages niay, however, be recovered in tort. ${ }^{2}$ The genesis of this distniction is the familiar rule of Hadley v. Baxendale ${ }^{3}$ which limits recovery in contract cases to those losses that are within the contemplation of the parties at the time of contracting and that can be ascertained with reasonable certainty. ${ }^{4}$ The establishnient of an objective, limited formula for damages in contract thus resulted in the American rule, precluding awards of punitive damages in contract actions, fron 1 which few courts to this day have chosen to depart. ${ }^{5}$

While the hinited form of recovery allowed in contract actions reflects an attitude of moral neutrality towards the breaching party, ${ }^{6}$ the

1. Restatement (SECOND) of CONTRACTS $\$ 355$ (1981); see infra notes 49-50 and accompanying text.

Punitive damages are also known as exemplary or vindictive damages, or "smart money." According to one commentator, they "are assessed for the avowed purpose of visiting a punishment upon the defendant and not as a measure of any loss or detriment of the plaintiff." C. MCCORMick, LAW OF DAMAGEs $\S 77$, at 275 (1935). Another commentator has similarly defined punitive damages as "sums awarded apart from any compensatory or nominal damages, usually as punishment or deterrent levied because of particularly aggravated misconduct on the part of the defendant." D. DobBs, HandBooK on the LAW OF Remedies § 3.9, at 204 (1973) (footnote omitted).

2. C. MCCORMick, supra note $1, \S 77$, at 275-76 (1935); W. Prosser AND W. KeETON, THE LAW OF TORTS $\S 2$, at 9 (5th ed. 1984). Recovery in tort is limited primarily by the requirement of "proximate cause"; that is, recovery in tort actions potentially consists of all damages proximately caused by the tortfeasor, as well as punitive damages. For other limitations on the right of an injured party to recover in tort, see ResTATEMENT (SECOND) OF TORTS $\$$ 918-923 (1977).

3. 9 Ex. 341, 156 Eng. Rep. 145 (1854).

4. Under the expectation measure, damages for breach of contract cannot exceed the expected "benefit of the bargain." RESTATEMENT (SECOND) OF CONTRACTS $§ 344$ (a) (1981). In other words, the expectation measure places the injured party "in as good a position as he would have been had the contract been performed." Id. This measure is limited, however, in that losses sustained in reliance on the contract are not compensable to the extent they exceed expectation damages. Id. $\S 349$ comment a. Furthermore, under the rule of Hadley v. Baxendale, recovery of consequential damages in contract is confined to those within the contemplation of the breaching party at the time the contract was made. In addition, recovery is limited to damages that can be proved with "reasonable certainty." Id. §352. Lastly, recovery or loss due to emotional disturbance is usually excluded altogether, unless the breach also caused bodily harm or the contract or breach was such that serious emotional disturbance was a likely result of the breach. Id. §353.

5. See infra notes 50-51 and accompanying text.

6. The neutrality of contract law towards the breaching party, however, is not absolute. While the focus of contractual remedies is normally on putting the promisee in as good a position as 
more expansive range of damages available in tort actions is predicated upon the concept of fault in a system of civil liability. ${ }^{7}$ In particular, the availability of punitive damages in tort is an explicit recognition of the role of punishment in a system having the inanifold objectives of deterrence, retribution, and compensation. But, despite the broad distinction between the availability of punitive damages in tort and their corresponding unavailability in contract, some exceptions exist, most of which have arisen out of the curious "borderland of contract and tort."8

In the "borderland," the plaintiff's right to recovery can arguably be found either in tort law or in contract law. Stated differently, the defendant's breach of a contractual duty is alleged to have also breached a tort duty owed to the plaintiff. In sonie cases, the plaintiff inay elect his ren1edy by clioosing to proceed either in tort or in contract. ${ }^{9}$ Thus, courts have witnessed plaintiffs' attenipts to plead tort causes of action by classifying contractual breaches as independent torts, ${ }^{10}$ as breaches of a fiduciary duty, ${ }^{11}$ or as breaches of an independent duty arising froin law. ${ }^{12}$ Most recently, courts have addressed atteinpts to construe the breach of the duty of good faith and fair dealing, implied in all contracts, as a tort. $^{13}$ Most of these cases have arisen in various commercial contexts.

he would have been had the contract been performed, the conduct of the promisor in breaching can affect the degree of certainty with which the promisee's losses must be proved. RESTATEMENT (SECOND) OF CONTRACTS $\$ 352$ (1981) ("A court may take into account all circumstances of the breach, including willfulness, in deciding whether to require a lesser degree of certainty." Id. $\S 352$ comment a). Moreover, the availability of expectation damages as a contractual reinedy reflects some sense of approbation towards the breaching party. See Fuller and Perdue, The Reliance Interest in Contract Damages, 46 YALE L.J. 52, 57-63 (1936).

7. Sullivan, Punitive Damages in the Law of Contract: The Reality and the Illusion of Legal Change, 61 MinN. L. REV. 207, 217-18 (1977).

8. See generally W. ProsSER, The Borderland of Tort and Contract, in SELECTED TopICS ON THE LAW OF TORTS 380 (1953) (discussing convergence of tort and contract and situations in which tort liability extends to contract actions).

9. Id. at 422-29. The plaintiff's choice of remedy may have other legal ramifications: it may affect the enforceability of a party's rights, the limitation of a term in the contract, the applicability of the statute of limitations or the statute of frauds, the choice of applicable law, or venue and jurisdiction. Generally, however, the importance to the plaintiff of the election between contract and tort concerns the measure of damages available. Where the plaintiff elects to proceed in tort, punitive dainages are often the goal.

10. See, e.g., Pringle Tax Serv., Inc. v. Knoblauch, 282 N.W.2d 151 (Iowa 1979) (owner of printing business, in breaching the noncompetition covenant of a sales agreenent with plaintiff, maliciously coinmitted tort of interference with business relationships); see also infra notes 78, 85-86 and accompanying text.

11. See, e.g., Vale v. Union Bank, 88 Cal. App. 3d 330, 151 Cal. Rptr. 784 (1979) (exemplary dainages inay be awarded against trustce who breaches his fiduciary duties where there is evidence of fraud, malice, or oppression); see also infra note 87 and accompanying text (jurisdictions in which punitive danages are available for breach of a fiduciary duty).

12. See, e.g., Gruenberg v. Aetna Ins. Co., 9 Cal. 3d 566, 510 P.2d 1032, 108 Cal. Rptr. 480 (1973) (insurer's breach of duty to deal fairly and in good faith with its insured may subject insurer to tort liability).

13. See, e.g., Seanan's Direct Buying Serv. v. Standard Oil Co., 36 Cal. 3d 752, 686 P.2d 1158, 
California courts have set the trend in this area, first by construing a breach of the imphied covenant of good faith and fair dealing to be tortious in the insurer-insured context, and later by expanding its applicability to the einployer-employee context and potentially to other cominercial contexts. ${ }^{14}$ The significance of a rule holding a breach of the implied covenant tortious is that it makes the breaching party subject to tort remedies, potentially including pumitive damages, rather than the traditionally limited remedies available in contract. ${ }^{15}$

The availability of pumitive damages $i m$ some of these cases accentuates not only the confusion regarding the proper classification of actions that fall in the borderland of contract and tort, but also the confusion concerning the proper standards for the imposition of punitive danages. Standards already criticized as vague ${ }^{16}$ becoine even more elusive when applied to cases that cannot easily be classified as either tort or contract. Consequently, few clear standards have been articulated for awards of punitive dainages in these cases.

In California, for example, in order to recover pumitive danages for a breach of the implied covenant of good faith and fair dealing, or for any other tort, the injured party inust show that the breaching party acted with "malice," "oppression," or "fraud."17 However, both courts and cominentators have found these ternis difficult to define. ${ }^{18}$ The California Supreine Court has held that "the ternıs 'good faith' and 'bad faith' are not meant to counote the absence or presence of positive imisconduct of a inalicious or immoral nature-considerations which ... are inore properly concerned in the determination of hability for punitive dainages." 19 That court has also concluded that a breach of the implied covenant of good faith and fair dealing does not entitle a plaintiff per se to punitive damages. ${ }^{20}$ Yet, despite these attempts to distinguish "bad

206 Cal. Rptr. 354 (1984) (oil dealer sued supplier for breach of contract and tortious breach of the implied covenant of good faith and fair dealing where supplier denied existence of a valid contract to supply dealer's fuel requirements).

14. See infra notes 89-106 and accompanying text.

15. In some situations contractual remedies may actually place the injured party in a better position than tort remedies. See D. LAYcock, Modern AMERICAN Remedies: CaSES AND MATERIALs 35-44 (1985), comparing Chatlos Sys. v. National Cash Register, 670 F.2d 1304 (3d Cir. 1982) (expectation damages properly awarded for breach of warranty) with Smith v. Bowles, 132 U.S. 125 (1889) (expectation damages improperly awarded for tort of fraudulent misrepresentation).

16. See, e.g., Ellis, Faimess and Efficiency in the Law of Punitive Damages, 56 S. CAL. L. REv. 1, 34-37 (1982); Comment, Punitive Damages in California Under the Malice Standard: Defining Conscious Disregard, 57 S. CAL. L. REV. 1065, 1065-67 (1984).

17. CAL. Civ. CodE $§ 3294$ (West Supp. 1985); see infra text accompanying notes 139-40.

18. See infra text accompanying notes 141-54.

19. Neal v. Farmers Ins. Exch., 21 Cal. 3d 910, 921-22 \& n.5, 582 P.2d 980, 986 \& n.5, 148 Cal. Rptr. 389, 395 \& n.5 (1978).

20. Id. at 922,582 P.2d at 986, 148 Cal. Rptr. at 395; Silberg v. California Life Ins. Co., 11 Cal. 3d 452, 456, 462-63, 521 P.2d 1103, 1106, 1110, 113 Cal. Rptr. 711, 714, 718 (1974). 
faitlı" (i.e., breacl1 of the implied covenant of good faith and fair dealing) from "malice," the court failed to further define the "malice" standard. Instead, the court imposed punitive damages in the insurer-insured context under the same rationale that it justified treating the breach of the implied covenant as a tort: the special relationship between the insurer and the insured. ${ }^{21}$ In another case, the court focused on "oppression" as the relevant standard for the imposition of punitive daniages. ${ }^{22}$ The net result of this variety of holdings is a vague set of standards for the imposition of punitive damages which in turn obscures the policies underlying punitive damage awards. This Comment attempts to resolve this ambiguity concerning awards of pumitive danıages in borderline cases through a historical evaluation of the doctrine of punitive damages and the rationales for their imposition. Part I describes the origins of punitive damage awards and their accompanying justifications and limitations. This Part explores the exclusion of punitive damage awards from contract actions, as well as two historical exceptions to the exclusionary rule. It then discusses the growth of exceptions to this rule in the borderland of contract and tort. Part II applies the historical rationales for awards of punitive danrages-compensation, punishment, and deterrence-to cases in the borderland, and concludes that of these, deterrence provides the only wholly satisfactory justification for sucl awards. Part III proposes a standard for awarding punitive damages im borderland cases in light of the justifications discussed in Part II.

This Comment argues that a standard for awarding punitive damages in borderland cases must be tailored to an objective measure of the defendant's actions-nanely, the extent of his departure froni commercially acceptable norins-rather than the defendant's subjective intent. Taking the California statutory standards for the imposition of punitive damages--that the defendant has acted with "malice," "oppression," or "fraud"- as a point of departure, this Comment concludes that "malice" is an inherently unworkable standard im borderland cases, and argues for the adoption of "oppression" as the proper standard. By focusing on an objective measure of the defendant's actions, this standard would maximize deterrence and thus better effectuate the policies underlying the imposition of punitive damages.

21. Egan v. Mutual of Omaha Ins. Co., 24 Cal. 3d 809, 820, 620 P.2d 141, 146, 169 Cal. Rptr. 691, 696 (1979), appeal dismissed and cert. denied, 445 U.S. 912 (1980).

22. Fletcher v. Western Nat'1 Life Ins. Co., 10 Cal. App. 3d 376, 89 Cal. Rptr. 78 (1970). 
I

LEGAL BACKGROUND

\section{A. The Historical Origins of Punitive Damages}

The availability of punitive damages in the modern context of the tortious breach of the implied covenant of good faith and fair dealing is directly analogous to contexts in which punitive damages were historically available. While the origins of punitive damages have been amply described elsewhere, ${ }^{23}$ a brief excursion into the historical underpinnings of the doctrine is useful in order to evaluate the current treatment of punitive damages in the borderland of contract and tort.

The doctrine of punitive damages appears to have emerged in eighteenth-century England in response to claims of excessive damage verdicts. ${ }^{24}$ Traditionally, jurors had unlimited discretion to award damages in excess of the plaintiff's tangible harms. ${ }^{25}$ This unfettered discretion was due in part to the origin of the jury itself as a substitute for ancient inethods of rendering judginents. The results of these methods, such as trial by ordeal and trial by battle, were thought to have been divinely ordained. ${ }^{26}$ In addition, since early juries were often coinposed of local townsmen who had personal knowledge of the facts of the case or of the parties and their estates, judges were reluctant, in the absence of any substantive law of damages, to set aside purportedly excessive verdicts. ${ }^{27}$ However, because juries could and frequently did award damages seemingly out of proportion to the actual losses, ${ }^{28}$ various

23. See, e.g., K. Redden, Punitive Damages $\S \S 2.2-.3$ (1980); 1 T. Sedgwick, A Treatise ON THE MEASURE OF DAMAGES $\$$ 348-351 (9th ed. 1913); Ellis, supra note 16, at 12-20; Rice, Exemplary Damages in Private Consumer Actions, 55 IowA L. REv. 307, 308-12 (1969); Sales \& Cole, Punitive Damages: A Relic That Has Outlived Its Origins, 37 VAND. L. REV. 1117, 1119-24 (1984); Sullivan, supra note 7, at 208-16; Note, Exemplary Damages in the Law of Torts, 70 HARV. L. REv. 517, 518-20 (1957). See generally Washington, Damages in Contract at Common Law, 47 LAW Q. REV. 345 (1931) (discussing assessment of contract damages at common law).

24. See K. REDDEN, supra note 23, $§ 2.2(\mathrm{~A})(2)$; 1 T. SEDGwick, supra note $23, \S 349$; Sullivan, supra note 7, at 210; Note, supra note 23, at 518-19.

A predecessor to the modern award of punitive damages was the practice in Roman law of awarding multiple damages, a remedy which, like modern punitive damages, allowed awards in excess of actual harm. The Code of Hammurabi in 2000 B.C. also provided a statutory remedy for the award of multiple damages, as did the Hittite law in 1400 B.C. and the Hindu Code of Manu in 200 B.C. The Bible also contains several examples of multiple damages under Hebrew law. See K. REDDEN, supra note 23, § 2.2(A)(1), at 26-28; Sales \& Cole, supra note 23, at 1119.

25. 1 T. SEDGWICK, supra note 23, § 349; Rice, supra note 23, at 308.

26. Sullivan, supra note 7, at 209 n.15 (citing 1 W. HOLDSWORTH, A HISTORY OF ENGLISH LAw 317 (7th ed. 1956)).

27. Sullivan, supra note 7, at 210. Indeed, it was not until 1622 that an English court implicitly recognized the power to set aside a jury verdict, although the court in that case declined to exercise such power on the ground that the jurors were more familiar with the quality and the estates of the particular parties and the damages inflicted by the defendant's slanderous act. Hawkins $v$. Sciet, 81 Eng. Rep. 1099 (K.B. 1622); see Ellis, supra note 16, at 12 (discussing Hawkins).

28. See Sullivan, supra note 7 , at 210 ; Note, supra note 23 , at 518-19. 
procedures developed whereby an allegedly excessive verdict could be reviewed.

The first such procedure was the writ of attaint. ${ }^{29}$ Like the modern motion for a new trial, the writ of attaint allowed inquiry into an allegedly erroneous verdict. The King or a magistrate assembled a panel of twenty-four grand jurors. If this panel found the verdict to be erroneous, it set aside the verdict and pumished the jurors. ${ }^{30}$ However, since this was an ad hoc procedure and because the penalties for a false verdict were so severe, ${ }^{31}$ the procedure failed to produce a coherent body of remedial law, and eventually fell into disuse. ${ }^{32}$

Instead, courts began to develop legal doctrines increasing their own power to revise jury verdicts. But because verdicts were still based in part on knowledge peculiar to the jurors, courts began to modify only those jury awards that were capable of objective verification. ${ }^{33}$ Thus, the courts began to distmguish between cases in contract and tort. In the former, such as cases brought on a writ of debt, damages were generally a matter of account to be reviewed and verified, and the court could therefore revise the verdict. ${ }^{34}$ Even in some cases sounding in tort, such as those involving solely the destruction of property, damages could be verified with accuracy and hence revised. ${ }^{35}$ Generally, however, the court still lacked the power to revise excessive verdicts in what now would be classified as tort actions, since the jury retained its witnessing function in fixing damages which were not capable of being ascertained with reasonable certainty.

In addition to inodifying jury verdicts, by the mid-seventeenth century courts began to exercise the power to order new trials as a means of controlhing excessive verdicts. However, courts maintained the distinction between tort and contract cases, and were reluctant to set aside verdicts and order new trials in tort cases. The doctrine of pumitive damages thus evolved for actions in which there were intangible harms. ${ }^{36}$

29. K. REDDEN, supra note $23, \S 2.2$; Sullivan, supra note 23, at 210-11; Note, supra note 23, at 519 n.16. See genterally Zane, The Attaint (pts. 1 \& 2), 15 Mrch. L. REv. 1, 127 (1916) (discussing history of proceeding by attaint and its successor, the motion for a new trial).

30. K. REDDEN, supra note $23, \S 2.2$; Sullivan, supra note 23 , at 211 ; Zane, supra note 29 , at 1 , 127; Note, supra note 23 , at 519 n.16.

31. The punishment for attainted jurors consisted of imprisonment, confiscation of all goods and possessions, and the destruction of houses and lands. T. PLUCKNETT, A CONCISE History OF THE COMMON LAW 131-34 (5th ed. 1956).

32. Attaint became obsolete by the 16 th century, after some 400 years of use. Sullivan, supra note 7 , at $210-11$.

33. Id. at 211 ; Ellis, supra note 16 , at 13.

34. Ellis, supra note 16, at 13 \& n.52 (citing Sharpe v. Brice, 96 Eng. Rep. 557, 557 (C.P. 1774)).

35. Ellis, supra note 16 , at 13 .

36. See K. REDDEN, supra note $23, \S 2.2(\mathrm{C})$ (compensation for intangible harms). 
Most commentators cite Huckle v. Money ${ }^{37}$ as the first case to award punitive damages. Indeed, the term "exemplary damages" appears to have originated with this case. In Huckle, the court denied a motion for a new trial on the ground of excessive damages even though the personal imjury to the plaintiff was very sniall. ${ }^{38}$ In upholding the award of exemplary damages against public officials for an illegal search and seizure under a general warrant, Lord Cainden pointed to the outrageous nature of the officials' actions, as they inust have appeared to the jurors, as the justification for the award. ${ }^{39}$

In a related case decided earlier that year, Wilkes $v$. Wood, ${ }^{40}$ Lord Chief Justice Pratt, without using the term "exemplary dainages," had expressed the view that a jury was not limited to awarding dainages for compensatory purposes:

[A] jury have it in their power to give damages for more than the mjury received. Damages are designed not only as a satisfaction to the injured person, but likewise as a punishment to the guilty, to deter from any such proceeding for the future, and as a proof of the detestation of the jury to the action itself. ${ }^{41}$

Although the reasoning of these early cases is not altogether clear, punitive damages apparently served to (1) compensate the victim for intangible losses connected to mental suffering and imjured feelings, (2) punish the defendant for his misdeeds and deter future misdeeds, and (3) express the jurors' outrage, as members of the community, towards the conduct of the defendant. ${ }^{42}$ In addition, some commentators have noted that punitive damages may have served to deter acts of vengeance by the plaintiff. ${ }^{43}$

Both English and early American cases reflect confusion as to whether damages were being awarded for exemplary or solely compensatory purposes. While Coryell v. Colbaugh, ${ }^{44}$ one of the first reported American cases awarding puntive dainages, stressed the pumitive and deterrent nature of the award, other cases emphasized the compensatory

37. 95 Eng. Rep. 768 (K.B. 1763). But see K. REDDEN, supra note 23, §2.2(A)(2), who attributes the proposition to Wilkes v. Wood, 98 Eng. Rep. 489 (K.B. 1763), discussed infra text accómpanying note 40.

38. 95 Eng. Rep. at 768.

39. Id. at 769 .

40. 98 Eng. Rep. 489 (K.B. 1763).

41. Id. at 498-99 (footnote omitted). But cf. $1 \mathrm{~T}$. SEDGwICK, supra note 23, § 350 (arguing that the early cases merely reflected a refusal on the part of the court to restrict the jury to certain damages).

42. For a discussion of the historical development of these rationales, see Rice, supra note 23 , at 309-12.

43. K. REDDEN, supra note $23, \S 2.2(\mathrm{~F})$ (discussing punitive damages as fulfilling the function of revenge); Ellis, supra note 16, at 17-18 (discussing revenge as an impetus for the legal system to award exemplary damages).

44. 1 N.J.L. 90 (Sup. Ct. 1791). 
function. ${ }^{45}$ Moreover, courts often confused the concepts of compensation and deterrence. An often quoted passage from a British case illustrates this point:

I wish to know, in a case where a man disregards every principle which actuates the conduct of gentlemen, what is to restrain him except large damages? . . . [Are we] to lay it down that the jury are not justified in giving more than the absolute pecuniary damage that the Plaintiff may sustain. ... Would that be a compensation? ${ }^{46}$

Regardless of what rationale supported the awards, by the end of the nineteenth century the doctrine of punitive damages was well established in England and in the United States. ${ }^{47}$ In addition, the distinction between the availability of punitive damages in tort actions and its unavailability in contract actions had become a feature of general damage law. ${ }^{48}$

\section{B. Punitive Damages in Contract Actions}

\section{The General Rule and Its Rationale}

As a general rule, exemplary damages may not be recovered in an action based on breach of contract. ${ }^{49}$ This common law Anverican rule has been codified in state statutes precluding awards of exemplary dan1ages for breaches "arising out of contract."50 Although some states have

45. See, e.g., Fay v. Parker, 53 N.H. 342, 355 (1873); Magee v. Holland, 27 N.J.L. 86 (Sup. Ct. 1858). Some commentators argue that the doctrine of punitive damages arose solely out of the desire of the courts to compensate plaintiffs for otherwise uncompensable injuries, such as the indignity and suffering inflicted upon the plaintiff. See J. Ghlard \& J. K1RCHER, Punitive Damages: LAw AND Practice $\S 1.02$, at 4-7 (1985 \& Cum. Supp. 1986); Mallor \& Roberts, Punitive Damages: Toward a Principled Approach, 31 Hastings L.J. 639, 642-43 (1980). As two commentators note, the term "smart money" was coined in Fay v. Parker to "refer to compensation for the indignity and suffering sustained by the plaintiff at the hands of the defendant-not damages that would make the defendant 'smart' in punishment for his offensive conduct." J. GHIARD1 \& J. KIRCHER, supra, $\S 1.02$, at 5 (citing $F a y$ ). A related theory argues that punitive damages arose to compensate the plaintiff for intangible harms, which courts were reluctant to accept as constituting "injury" and which were also not susceptible of precise measurement. Id. at 4.

46. Merest v. Harvey, 5 Taunt. 442, 128 Eng. Rep. 761 (C.P. 1814).

47. Sullivan, supra note 7 , at 216 ; see also $1 \mathrm{~T}$. SEDGWICK, supra note 23 , $\$ 351$ (doctrine was established by middle of the nineteenth century). Punitive damages are currently available in all but four jurisdictions in the United States, and in only one state, Nebraska, have punitive damages been found unconstitutional. Comment, Punitive Damages: An Appeal for Deterrence, 61 NEB. L. REV. $651,651 \&$ n.2 (1982).

48. 1 T. SEDGWICK, supra note $23, \S \S 350-352$.

49. Restatement (Second) of Contracts $§ 355$ (1981); 5 A. Corbin, Corbin on ConTRACTS $\S 1077$, at 438 (1964); K. REDDEN, supra note 23, §§ 4.3-.3(A) (Cum. Supp. 1986); see, e.g., Splitt v. Deltona Corp., 662 F.2d 1142 (5th Cir. 1981) (interpreting Florida law); Cochran v. Hall, 8 F.2d 984 (5th Cir. 1925) (interpreting Texas law); Phillips Mach. Co. v. Le Blonde, Inc., 494 F. Supp. 318 (N.D. Okla. 1980) (interpreting Oklahoma law); Minnesota-Iowa Television Co. v. Watonwan T.V. Improvement Ass'n, 294 N.W.2d 297 (Minn. 1980).

50. See, e.g., CAL. Civ. Code $\S 3294$ (West Supp. 1986), GA. Code ANN. $\$ 20-1405$ (1977), Nev. Rev. Stats. § $42-010$ (1973), S.D. COMP. LAwS ANN. § 21-3-2 (1979). 
allowed punitive damages for a sufficiently outrageous breach of contract, they are in the ininority. ${ }^{51}$ One historical explanation for the American rule, referred to earlier, is that because contractual damages were capable of precise measurement, judges were able to limit jurors' discretion to award verdicts in excess of actual damages; ${ }^{52}$ thus, in contract cases, there was no need for a body of doctrine-necessary im tort cases-to justify excessive verdicts which tlie courts were reluctant to set aside.

Altlough the disparate treatment of damage awards im contract and tort cases can in part be explamed historically, the survival of the dichotomy between tort and contract derives largely from the theoretical underpinnings of the law of contractual reniedies. Tlie prohibition against punitive damages in contract actions is the logical corollary of Oliver Wendell Holmes's theory of efficient breach. According to this theory, the law should not imipose on the promisor the obligation to perforn if the promisee can be fully conipensated by receiving the inonetary benefit of the contract. ${ }^{53}$ Thus, the promisor should be free to breach her contractual promise if by doing so she is able to reap economic gains, taking the cost of breaching into account. The law thus encourages "efficient breaches," which produce a net gain for society because goods and services are allocated to their most valued users. ${ }^{54}$

Witlim certain limits, contracting parties may set their own standards of conduct, as well as the sanctions for breaches, through the free exercise of their power to contract. Parties niay contractually agree upon the costs that a party must pay im order to breach and the remedies available to the nonbreaching party. The role of the courts is to affirm the contractual expectations of the nonbreaclimg party by putting her in as good a position as sle would have been in had the contract been perforned. Hence, in contract law, there is "no necessity for satisfying... [the imjured party's] feelimgs and allaymg community resentment by fines or physical punisliment." 55

51. At least four states have adopted this position: Florida, Indiana, Michigan, and Ohio. Comment, supra note 16, at 1077 n.84. Two other states, South Carolina and Texas, may extend the doctrine of punitive damages to some contractual matters. See K. REDDEN, supra note $23, \S 2.6$, at 42; Rice, supra note 23, at 314. See generally J. MCCARThy, Punitive Damages in Bad Faith CASES $\$ 1.42$, at 92 (3d ed. 1983).

52. See infra notes $33-35$ and accompanying text.

53. O.W. Holmes, THE COMMON LAw 236 (1963). The law is thus concerned with compensating the promisee for pecuniary losses in order to put the promisee in the same position as if the promise had been performed. Therefore, the defendant's conduct in breaching is largely irrelevant; there is no social approbation under the law for the failure to keep one's promises in an economic setting. But see supra note 6.

54. Restatement (SECOND) OF CoNTRACTS $\$ 344$ reporter's note at 106 (1981); R. PosNER, Economic ANALySis of ThE LAW §4.8, at 106-08 (1986); Cooter, Prices and Sanctions, 84 Colum. L. Rev. 1523, 1544-45 (1984).

55. 5 A. CoRBin, supra note $49, \S 1077$, at 438 . 
In contrast, one purpose of damages in tort, especially punitive damages, is an "explicit recognition of the manifold role of punishment in a system of liability for civil wrongs which turns upon the concept of fault." 56 According to Corbin, this difference is the central rationale for the American rule:

In the innumerable cases arising from the breach of an ordinary commercial contract, it seemed wise to adhere to the general rule excluding the punitive element and to avoid the frequently futile attempt to determine the degree of moral obliquity. The uncertainties involved in estimating pecuniary harms are such as to give to trial judge and jury sufficient latitude in awarding damages, as between those whose conduct shows no lack of honesty and good faith and those whose breach is due to malice and avarice. ${ }^{57}$

Corbm thus found that the flexibility provided by the damage formulas in contractual cases allowed enough latitude to take account of other implicit goals of the damage law, such as deterrence of breach and revenge..$^{58}$

Some commentators now argue, however, that the law should encourage parties to keep their promises by imposing greater liability on the breaching party. ${ }^{59}$ These cominentators note that the rules of limited hability in contract law arose in the nineteenth century as a response to the same stimuli that produced the theoretical system of laissez-faire economics, industrialization, and the newly emerging status of the individual. One commentator observes:

As we look back on the nineteenth century theories, we are struck most of all, I think, by the narrow scope of social duty which they implicitly assumed.... The decline and fall of the general theory of contract and, in most quarters, of laissez-faire economics may be taken as remote reflections of the transition from nineteenth century individualism to the wel-

56. Sullivan, supra note 7 , at $217-18$ (footnote omitted). Indeed, tort law is not concerned solely with the compensation of victims, or else no moral approbation for the wrong would rest with the tortfeasor. $Y d$.

57. 5 A. CORBIN, supra note $49, \S 1077$, at 440 .

58. One commentator, however, has theorized that this very flexibility demonstrates the functional similarities between damages in contract and tort. Sullivan, supra note 7, at 219-20. Sullivan argues that some commentators such as Corbin and Prosser recognize that damages for breach of contract can serve other purposes besides compensation, such as deterrenee and punishment, and that the uncertainties behind awards of damages in contract actions disguise the extent to which this is true. $I d$. at 219 \& n. 77 (citing 5 A. CoRBIN, supra note $49, \S 1002$, at 33 and W. Prosser, HandBook OF tHe LAW OF TORTS $\S 4$ at 23, $\S 5$ at 17 (4th ed. 1971)).

59. See G. Gilmore, The DeAth of Contract 94-103 (1974); see also Holmes, Is There Life After Gilmore's Death of Contract? - Inductions from a Study of Commercial Good Faith in First-Party Insurance Contracts, 65 CoRNELL L. REv. 330, 334 (1980) (arguing that contract law has increasingly relied on fault as an element of liability as a response to the limits, rather than the death, of a consensual contract theory that reduces contractual relations to a "primitive battle for the survival of the fittest."). 
fare state and beyond. ${ }^{60}$

Some commentators thus question the utility and the acceptability of limiting liability to expectation damages in contractual contexts in the modern industrialized state. ${ }^{61}$ Some also see the growth of specialized bodies of law, sucli as antitrust, insurance, and business regulation, as a reaction to the perceived inadequacies of contract law to deal with the reality of economic relations. ${ }^{62}$

\section{Two Historical Exceptions}

The American rule excluding punitive awards in contractual cases has been subject to exceptions since its inception. The two most commonly cited examples are contracts to marry and public service contracts. $^{63}$ The first of these, breach of a contract to marry, rests upon the dichotomy between tort and contract: punitive damages are awarded because the breacli is accoinpanied by reprehensible conduct amounting to an imdependent tort. ${ }^{64}$ The tortious nature of the breacli, similar to the tort of intentional infliction of emotional distress, allows the planitiff to collect punitive damages. This exception also exhibits the element of intangible harm seen in the cases that precipitated the doctrime of punitive damages, which perhaps explams its early and widespread acceptance. $^{65}$ Breach of a contract to marry alone will not necessarily entitle the plaintiff to an award of punitive damages, but courts allow the imposition of punitive damages under a variety of standards, by finding the breach fraudulent, inalicious, or ruthless. ${ }^{66}$

The second exception to the general rule excluding punitive awards in contractual cases, breach of a public service contract, owes its origin to early English law regarding common callings. ${ }^{67}$ As two commentators have explained:

The relationship at early common law between purveyors of goods and services and the consuming public was one of status, involving tlie concept of a 'public' or 'common' calling or, to use a later phrase, an enter-

60. G. GlLMORE, supra note 59, at 95-96 (footnote omitted).

61. See, e.g., Danzig, Hadley v. Baxendale: $A$ Study in the Industrialization of the Law, $4 \mathrm{~J}$. Legal STUd. 249, 277-84 (1975); Tobriner \& Grodin, The Individual and the Public Service Enterprise in the New Industrial State, 55 CAL1F. L. REv. 1247, 1247-49, 1251-54 (1967); J. Galbratth, The New INDUSTR1Al State 23-26 (1967).

62. L. Friedman, CONTRACT LAW in AMERICA 20-24 (1965). The growth of the doctrine of unconscionability is a recent example of this phenomenon. Holmes, supra note 59, at 334.

63. See K. REDDEN, supra note $23, \S 2.5$.

64. Id. $\S \S 2.5,4.3$.

65. Sullivan, supra note 7, at 222-23.

66. Id.; Note, Punitive Damgaes in Contract Actions - Are the Exceptions Swallowing the Rule?, 20 WASHBURN L.J. 86, 94 (1980).

67. Sullivan, supra note 7, at 223-24. See generally W. Prosser, supra note 8, at 402-07; Burdick, The Origin of the Peculiar Duties of Public Service Companies, 11 Colum. L. Rev. 514 (1911). 
prise 'affected with a public interest.' Because such enterprises 'held themselves out' as providing a particular product or service to the coinmurity, the common law attaclied to them certain obligations, including-at various stages of doctrinal development-the duty to serve all customers on reasonable terms without discrimination and the duty to provide the kind of product or service reasonably to be expected from their economic role. ${ }^{68}$

The law imposed such duties upon common callings because of the monopoly position they enjoyed in medieval society and the consequent potential for abuse or oppression of the public by them. ${ }^{69}$ Providers of services affected included the innkeeper, the blacksmith, the foodseller, and the common carrier. ${ }^{70}$ There thus existed what now would be termed a special relationship between the provider of the goods or services and the public. ${ }^{71}$

The doctrine of common callings evolved into the modern exception that allows awards of puritive damages in breach of contract actions involving enterprises affected with a public interest, ${ }^{72}$ such as common carriers, water, gas and electric companies, telephone and telegraph companies, and banks. ${ }^{73}$ In such cases, the plaintiff may elect to bring the action in contract or in tort. Liability in tort arises out of a duty or relation between the parties, of which the contract is merely an incident; such liability is imposed by the law out of concern for the potential for abuse inherent $\mathrm{m}$ the monopoly position enjoyed by such companies. ${ }^{74}$ As with the exception for breach of a contract to marry, however, courts disagree as to the standard of conduct the plaintiff should be required to prove in order to receive pumitive damages, beyond the negligent performance of services or the merely neghigent failure to provide services. ${ }^{75}$

\section{The New Borderland of Contract and Tort: Recent Exceptions}

The historical exceptions to the prohibition against exemplary damages in contract actions discussed above have spawned a number of more recent exceptions. ${ }^{76}$ Modern courts have permitted recovery of punitive damages for (1) breach of contract accompanied by fraud, ${ }^{77}(2)$ breach of

68. Tobriner \& Grodin, supra note 61, at 1249-50 (footnotes omitted).

69. Sullivan, supra note 7 , at 224 .

70. Tobriner \& Grodin, supra note 61 , at $1249-50$.

71. Id. at $1249 \&$ n. 13.

72. Sullivan, supra note 7 , at 224 .

73. See Note, supra note 66 , at 94 , and cases cited therein; see also K. REDDEN, supra note 23 , $\S 4.4(\mathrm{~A})$ (telephone, telegraph, and utility companies).

74. C. MCCoRM1CK, supra note 1 , § 81; D. DoBss, supra note 1 , 3.9.

75. C. MCCORMICK, supra note 1 , § 81; W. Prosser, supra note 8, at 389-90, 402-05.

76. For a short summary of the exceptions, see Note, supra note 66, at 93-96.

77. See infra note 82 . 
contract accompanied by mdependently tortious conduct, ${ }^{78}$ (3) breach of a fiduciary duty, ${ }^{79}$ and (4) breach of the imphed covenant of good faith and fair dealing. ${ }^{80}$ Although these exceptions may appear to fall imto rigid categories, the categories overlap considerably.

The requirements for fraudulent breach of contract have been variously defined. ${ }^{81}$ Some jurisdictions allow punitive damages when the breach of contract is accompanied by or accomplished through fraudulent conduct. ${ }^{82}$ This formulation of the exception is quite broad because courts often define fraud expansively and because fraudulent conduct can accompany all contractual relations. This exception leads to unpredictable results since the level of proof required to show fraud may often be unclear. ${ }^{83}$

Another formulation ouly allows pumitive damages when breach of contract is accompanied by or accomplished through conduct aniounting to an independent tort. ${ }^{84}$ In one sense, this limits the exception, since the fraudulent conduct must be independently tortious. ${ }^{85}$ Yet this exception is potentially niore expansive than the previous one in that the tortious conduct need not be fraudulent. The problem, of course, is in distinguishing conduct that falls in the borderland of tort and contract. ${ }^{86}$

Breacl of a fiduciary duty can also lead to punitive damages in some jurisdictions. ${ }^{87}$ Here, breach of the fiduciary duty created by the rela-

78. See, e.g., Hibschman Pontiac, Inc. v. Batchelor, 266 Ind. 310, 314, 362 N.E.2d 845, 847 (1977) (automobile dealer's failure to make repairs supported finding of elements of tort-fraud, malice, gross negligence or oppression-mingled with breach of warranty; finding of either independent tort or elements of tort sufficient to justify award of punitive damages); Brink's Inc. v. City of New York, 717 F.2d 700, 704-05 (2d Cir. 1983) (puritive damages properly awarded under New York law where armored-car carrier was negligent im hiring and supervising employees under a contract with the city to collect revenues).

79. See infra note 87.

80. See infra notes $89,92-106$.

81. See Comment, Punitive Damages on Ordinary Contracts, 42 Mont. L. Rev. 93, 95-96 (1981) (tracing development of exceptions to the American rule against punitive damages in contract actions in Montana).

82. Id. at 95; see, eg., Powers v. Martinson, 313 N.W.2d 720, 727-28 (N.D. 1981) (punitive damages properly awarded where defendant committed fraud in sale of building); Peterson v. Culver Educ. Found., 402 N.E.2d 448, 453-57 (Ind. Ct. App. 1980) (elements of fraud, malice, gross negligence, or oppression combined with breach of contractual promises may support award of punitive damages).

83. See Comment, Exemplary Damages in Contract Cases, 7 Willametre L. Rev. 137, 14046, 149-50 (1971) (surveying laws of Oregon, California, and South Carolina and arguing that the differing definitions of "fraudulent breach" are confusing and undesirable).

84. See supra note 78.

85. See Comment, supra note 81 , at 95.

86. Arguably, awards of punitive damages for the independent tort do not violate the prohibition against punitive damages for breach of contract. But see Sullivan, supra note 7, at 236-37 (concluding that although courts do award punitive damages on the basis of finding an independent tort, such an approach is essentially specious because it assumes that the line between contract and tort can be drawn precisely); Comment, supra note 83, at 138-39.

87. See, e.g., Ramsey v. Culpepper, 738 F.2d 1092, 1099 (10th Cir. 1984) (failure of a realtor to 
tionship between the parties, rather than the contract itself, entitles the plaintiff to exemplary damages. ${ }^{88}$ Thus the central inquiry under this approach is whether the contract creates a relationship between the parties that is fiduciary in character.

But the most recent and potentially far-reaching exception is the one that allows punitive damages for a breach of the implied covenant of good faith and fair dealing, or as one court has called it, the tortious breach of contract. ${ }^{89}$ This exception closely resembles the independenttort exception because breach of the implied duty of good faith, irrespective of whether there has been a breach of the express terms of the contract, leads to the imposition of tort hability. ${ }^{90}$ California courts are largely responsible for the development of this new tort, which so far has niostly been confined to insurance cases. ${ }^{91}$

In Comunale v. Traders \& General Insurance Co., ${ }^{92}$ the California Supreme Court defined the scope of the relevant duty by stating, "There is an implied covenant of good faith and fair dealing in every contract that neither party will do anything which will injure the right of the other to receive the benefits of the agreement." Wh While Comunale involved a "third-party action" (the msured was seeking indemnification

disclose important information to a fiduciary, if willful or wanton, can be basis for a punitive damage award); Brown v. Coates, 253 F.2d 36, 39-41 (D.C. Cir. 1958) (punitive damages properly imposed on real estate broker who breached fiduciary duties by fraudulently inducing homeownwers to convey their house to him); Capitol Fed. Sav. \& Loan Ass'n v. Hohman, 235 Kan. 815, 816, 682 P.2d 1309, 1310 (1984) (defendant vendor's breach of a fiduciary duty to home purchasers constituted independent tort that supported award of punitive damages); Mulder v. Mittelstadt, 120 Wis. 2d 103, 117-18, 352 N.W.2d 223, 230 (Ct. App. 1984) (punitive damages awarded for defendant's willful and wanton violations of fiduciary duties to plaintiff corporation).

88. K. REDDEN, supra note 23, $\S 4.3$ (A), at 176 (Cum. Supp. 1986).

89. Seaman's Direct Buying Serv. v. Standard Oil Co., 36 Cal. 3d 752, 769, 686 P.2d 1158, 1167, 206 Cal. Rptr. 354, 363 (1984).

90. See Louderback \& Jurika, Standards for Limiting the Tort of Bad Faith Breach of Contract, 16 U.S.F. L. REV. 187, 197-98 (1982). This exception also resembles the breach-of-fiduciary-duty exception in certain contexts where breach of the implied covenant is dependent on a "special relationship" between the parties. For analyses of the growth of this exception, see Comment, Reconstructing Breach of the Implied Covenant of Gcod Faith and Fair Dealing as a Tort, 73 CALIF. L. REV. 1291 (1985) [hereinafter Comment, Reconstructing Breach of the Implied Covenant]; Comment, Tort Remedies for Breach of Contract: The Expansion of Tortious Breach of the Implied Covenant of Good Faith and Fair Dealing into the Commercial Realm, 86 CoLuM. L. REv. 377 (1986) [hereinafter Comment, Tort Remedies for Breach of Contract]; Comment, Sailing the Uncharted Seas of Bad Faith: Seaman's Direct Buying Service, Inc. v. Standard Oil Co., 69 MiNN. L. REv. 1161 (1985) [hereinafter Comment, Sailing the Uncharted Seas]; Note, "Contort": Tortious Breach of the Implied Covenant of Good Faith and Fair Dealing in Noninsurance, Commercial Contracts-Its Existence and Desirability, 60 NOTRE DAME L. REv. 510 (1985).

91. For a summary of the cases, see generally J. MCCARTHY, supra note 51; Louderback \& Jurika, supra note 90, at 197 n.46 (citing legal commentary on bad faith breach of contract in the insurance field); Comment, Reconstructing Breach of the Implied Covenant, supra note 90, at 129396.

92. 50 Cal. $2 d 654,328$ P.2d 198 (1958).

93. Id. at $658,328 \mathrm{P} .2 \mathrm{~d}$ at 200 . 
for the insurer's failure to defend him in a third-party action and to accept a reasonable offer), subsequent cases have applied the duty to "first-party actions." 94 In a first-party action, the insured usually has been denied the benefits of the policy through questionable conduct on the insurer's part. Examples of first-party cases include Neal v. Farmers Insurance Exchange, ${ }^{95}$ in which an insurer refused to compensate its insured for a loss covered by the policy even though it had no colorable defense to the insured's claim, and Silberg v. California Life Insurance Co., ${ }^{96}$ in which an insurer construed an ambiguity in the insurance contract in its own favor.

Two commentators, Louderback and Jurika, have identified four factors common to the cases creating this exception:

(1) [O]ne of the parties to the contract enjoys a superior bargaining position to the extent that it is able to dictate the terms of the contract; (2) the purpose of the weaker party in entering into the contract is not primarily to profit but rather to secure an essential service or product, financial security or peace of mind; (3) the relationship of the parties is such that the weaker party places its trust and confidence in the larger entity; and (4) there is conduct on the part of the defendant indicating an intent to frustrate the weaker party's enjoyinent of the contract rights. ${ }^{97}$

These four factors, developed by Louderback and Jurika to distinguish a tortious breach of the implied covenant of good faith and fair dealing froin an ordinary breach of contract, have had a "substantial impact on the developing law in Cahifornia."98

The California Suprene Court, utilizing similar criteria, opened the door for the extension of the exception beyond the realm of insurance cases to other commercial contexts in Seaman's Direct Buying Service v. Standard Oil. ${ }^{99}$ While the court's analysis of the exception relied upon the "special relationship" criteria developed by Louderback and Jurika, the court declined to decide whether a breach of the implied covenant of

94. Silberg v. California Life Ins. Co., 11 Cal. 3d 452, 521 P.2d 1103, 113 Cal. Rptr. 711 (1974); Gruenberg v. Aetna Ins. Co., 9 Cal. 3d 566, 510 P.2d 1032, 108 Cal. Rptr. 480 (1973). While nearly all jurisdictions that have considered the issue recognize a cause of action in tort for thirdparty cases, a lesser number (although still a majority) recognize a cause of action for first-party cases. See S. Ashley, Bad Faith Actions: Liability and Damages $§ 2: 22$ (1986 \& Supp. 1987).

95. 21 Cal. 3d 910, 582 P.2d 980, 148 Cal. Rptr. 389 (1978).

96. 11 Cal. 3d 452, 521 P.2d 1103, 113 Cal. Rptr. 711 (1974).

97. Louderback \& Jurika, supra note 90 , at 227 . The commentators argue that the tort of bad faith should be applied to commercial contracts only if these four criteria are met. Id.

98. See S. ASHLEY, supra note $94, \S 11: 03$. Ashley criticizes these criteria as underinclusive in that they have the virtue of including most insurance cases but the shortcoming of excluding almost every other kind of breach of contract. Id. § 11:04. More fundamentally, Ashley rejects the criteria because "they do a poor job of explaining the insurance cases themselves." Id. For another critique rejecting the Louderback and Jurika approach, see Comment, Reconstructing Breach of the Implied Covenant, supra note 90 , at 1299-1301.

99. 36 Cal. 3d 752, 686 P.2d 1158, 206 Cal. Rptr. 354 (1984). 
good faith and fair dealing could give rise to a tort action in ordinary commercial contracts. ${ }^{100}$ Instead, the court based tort liability upon the bad faith denial of the existence of a contract without detailing standards to distinguish good faith denial fron bad faith denial. ${ }^{101}$

While the reaction of California courts of appeal to Seaman's has been mixed, ${ }^{102}$ California courts have used sinilar criteria to expand the tort of unfair dealing beyond the insurance context to the at-will employnent context, ${ }^{103}$ and the California Suprenie Court has indicated its approval by way of dictuni. ${ }^{104}$ In Wallis v. Superior Court, ${ }^{105}$ an appellate court classified a breach of an einployment contract as a tort, based on its analysis of criteria similar to those articulated by Louderback and Jurika. However, in addition to these, the court considered a fifth factor: ordinary contract daniages are not adequate because (a) they do not require the party in the superior position to account for its actions, and (b) they do not inake the inferior party whole. ${ }^{106}$ At least one court of appeal has extended the tort of unfair dealing even further to the banking-depositor context. ${ }^{107}$

As will be explored further in Part II, the exception allowing awards of punitive daniages for a breach of the implied covenant of good faith and fair dealing is justified under a similar rationale to that underlying the historical exceptions for breach of a contract to nuarry and public service contracts. Yet the standards for awarding punitive daniages for a breach of the imphed covenant remain ill defined. Part III thus will attempt to elucidate such standards.

100. Id. at 768-69, 686 P.2d at 1166, 206 Cal. Rptr. at 362 .

101. Id. at 769, 686 P.2d at 1167, 206 Cal. Rptr. at 363.

102. See Comment, Tort Remedies for Breach of Contract, supra note 90, at 389-90.

103. Wallis v. Superior Court, 160 Cal. App. 3d 1109, 207 Cal. Rptr. 123 (1984); Cleary v. American Airlines, 111 Cal. App. 3d 443, 168 Cal. Rptr. 722 (1980).

104. The California Supreme Court indicated its approval of the extension of the tort to the employment context in Seaman's Direct Buying Service v. Standard Oil Co., 36 Cal. 3d 752, 769 n.6, 686 P.2d 1158, 1166 n.6, 206 Cal. Rptr. 354, 362 n.6 (1984), and in Tameny v. Atlantic Richfield Co., 27 Cal. 3d 167, 179 n.12, 610 P.2d 1330, 1337 n.12, 164 Cal. Rptr. 839, 846 n.12 (1980). Montana and Rhode Island have applied the tort of unfair dealing to the employer-employee relationship as well. See J. McCarthy, Punitive Damages in Wrongful Discharge Cases $\S 2.2$, at 81-86 (1985); Comment, Tort Remedies for Breach of Contract, supra note 90, at 384-86 (citing cases).

105. 160 Cal. App. 3d 1109, 207 Cal. Rptr. 123 (1984).

106. Id. at 1118, 207 Cal. Rptr. at 129.

107. Commercial Cotton Co. v. United Cal. Bank, 163 Cal. App. 3d 511, 209 Cal. Rptr. 551 (1985) (bank's refusal to pay a depositor for a forged check when the bank asserted a nonexistent legal defense warranted an award of punitive damages). 
II

\section{IDENTIFYING A RATIONALE FOR AWARDS OF PUNITIVE DAMAGES IN BORDERLAND CASES}

In order to explicate a rationale for punitive damage awards in cases in the borderland of contract and tort, we inust return to an examination of the theoretical rationales underlying the American rule regarding contract reniedies.

The general rule prohibiting awards of punitive damages in contract actions arose out of a legal conception of the individual created in the nineteenth century that facilitated the growth of the inodern economic 1narket. ${ }^{108}$ The rule still serves the policies underlying freedoni of contract where there is a meaningful exercise of contractual wills, as when the contract results froin bargaining between sophisticated parties. This conception, however, no longer comports with reality in many economic transactions, especially those between consuniers and large corporate institutions. ${ }^{109}$ Where contractual freedont no longer exists in a neaningful sense, as when the consumer lias no choice but to accept the terms offered by a corporate institution offering vital services, courts have begun to return to the concept of status to enforce the obligations of contracting parties. ${ }^{110}$

One device used to enforce obligations in this situation is the covenant of good faith and fair dealing. As one cominentator has noted, "This covenant represents a fundaniental policy shift away from the unbridled freedom froin the obligation of contract performance toward the fulfillinent of the reasonable expectations of the parties by encouraging performance." 111 The covenant of good faith and fair dealing resenbles both of the historical exceptions to the general rule prohibiting punitive damages-breach of a public service contract and breach of a contract to marry-in that all are exaniples of the common law choosing to retain the concepts of status and relations between the parties in enforcing obligations.

Consideration of a typical defendant in a case based on a breach of the implied covenant will illustrate the similarity of such cases to the historical exceptions. The defendant, often an insurance corporation, occupies a certain status in modern society. It holds itself out as providing an essential service to the community: protection against unexpected loss. Moreover, the insurance company, at least in the context of consumer transactions, generally is able to dictate the terms of the contract through the use of standardized contracts and its superior bargaining

108. See supra text accompanying notes 59-62.

109. Holmes, supra note 59, at 330-35; Rice, supra note 23, at 307.

110. See supra text accompanying notes 76-106.

111. Holmes, supra note 59, at 332 . 
position. ${ }^{112}$ As there is likely to be little excliange of information among consumers in these transactions, the potential for abuse or oppression is high. Thus, it is not surprismg that the law lias begun to impose an obligation on insurers to provide the kind of service reasonably to be expected because of their status and economic role.

The imposition of punitive damages in this context is thus analogous to the historical exception of public service contracts, in which the relationship between the provider and the public, together witl the provider's status in the community, justified the imposition of punitive damages. Furtliermore, the plaintiff in an insurance case typically seeks to contract with the defendant not only for a service but also for peace of mind and security. ${ }^{113}$ Breach of sucli a contract results in intangible loss similar to losses caused by a breach of a contract to marry or intentional infliction of emotional distress-situations where punitive damages historically have been thought appropriate. Awarding punitive damages for a breach of the implied covenant is hence consistent with earlier exceptions allowing pumitive damages in contractual actions, and therefore should be examined in light of the historical justifications for the imposition of pumitive damages: compensation, punishment, and deterrence.

\section{A. Compensation}

Compensation is generally concerned witl making the plaintiff whole, that is, compensating her for all consequential losses including those due to mental suffermg and other intangible losses. Once the breach of the implied covenant is classified as a tort, however, full compensatory damages (imcluding intangible losses) become available to the plaintiff and fulfill this function. ${ }^{114}$ Moreover, in a recent case, the California Supreme Court has held that a plaintiff is entitled to attorneys' fees as part of losses "proximately caused" by an insurer's breach of the implied covenant of good faith and fair dealing. ${ }^{115}$ The availability of

112. See Louderback \& Jurika, supra note 90 , at $200-01 \&$ n.63 (discussing adhesionary characteristics of insurance contracts).

113. See Crisci v. Security Ins. Co., 66 Cal. 2d 425, 434, 426 P.2d 173, 179, 58 Cal. Rptr. 13, 19 (1967):

Among the considerations in purchasing liability insurance, as insurers are well aware, is the peace of mind and security it will provide in the event of an accidental loss, and recovery of damages for mental suffering has been permitted for breach of contracts which directly concern the comfort, happiness or personal esteem of one of the parties.

114. Comment, Reconstructing Breach of the Implied Covenant, supra note 90, at 1326; see also C. MCCoRMICK, supra note $1, \S 77$, at 275 (author largely excludes the compensatory function by his formulation of punitive damages).

115. Brandt v. Superior Court, 37 Cal. 3d 813, 693 P.2d 796, 210 Cal. Rptr. 211 (1985). In both Connecticut and Idaho, awards of punitive damages have been expressly linked to compensation for attorneys' fees. See Collens v. New Canaan Water Co., 155 Conn. 477, 488, 234 A.2d 825, 831-32 (1967) (holding that punitive damages are compensatory in nature and may not exceed plaintiff's litigation expenses, minus taxable costs); see also United Aircraft Corp. v. International Ass'n of 
attorneys' fees is an especially significant developnent inasniuch as punitive damages are sonietimes justified as a neans of conpensating the defendant for the actual costs of hitigation. Thus, conipensation is not a sufficient justification for the iniposition of punitive damages for breach of the iniplied covenant since the plaintiff is already entitled to full con1pensatory daniages whien breach of the implied covenant is classified as a tort.

Related to the rationale that punitive damages serve to compensate for the actual costs of litigation is the notion that punitive daniages serve as "bounty" for tlie plaintiff, encouraging him to act as a "private attorney general." "116 Two ideas lie behind this rationale. First, public interest requires that the defendant be punished for his actions, and punitive damages provide an incentive to sue where the plaintiff might not otherwise do so. Where tlie defendant is unlikely to be prosecuted criminally, this may ensure that lie does not go entirely unpunished. ${ }^{117}$ Furtherniore, where there are gaps in the crimmal law, there inay be a convincing rationale for the imposition of punitive damages. ${ }^{118}$ The imitiation of civil suits in this context nray also discourage plaintiffs' attempts to go outside the law to seek revenge. ${ }^{119}$

Second, punitive damages provide an incentive to sue where the defendant has liarmed niany individuals but is unlikely to be sued due to the relatively small recovery for any individual planitiff and the ligh costs of litigation. ${ }^{120}$ To the extent that attorneys' fees are available for breach of the iniplied covenant, this rationale fails to justify the imposition of punitive damages. But to the extent that tle costs of litigation (including attorneys' fees) are not recoverable, this rationale niay support the award of punitive daniages for breach of the iniplied covenant, particularly in the insurance, einploynient, and consumer contexts, where the individual niglit not otherwise sue due to the presence of tlie factors

Machinists, 161 Conn. 79, 106, 285 A.2d 330, 345 (1971), cert. denied, 404 U.S. 1016 (1972) (plaintiff entitled to recover punitive damages in an amount that would serve to compensate plaintiff for litigation expenses less taxable costs); Erhardt v. Leonard, 104 Idaho 197, 202, 657 P.2d 494, 499 (Ct. App. 1983) (punitive damages may be awarded to compensate plaintiff for necessary and reasonable attorneys' fees and expenses).

Ghiardi and Kircher reject this rationale for the imposition of punitive damages as an indirect attack on the Ameriean rule that each party in a civil suit must bear his own litigation expenses. J. GHIARDI \& J. KIRCHER, supra note 45, § 2.11, at 25-26; see also Long, Punitive Damages: An Unsettled Doctrine, 25 DRAKE L. REv. 870, 875-76, 888 (1976) (arguing that the all-encompassing nature of compensatory damages has rendered punitive damages "superfluous in terms of indemnity").

116. See D. DoBbs, supra note $1, \S 3.9$, at 205 ; K. REDDEN, supra note $23, \S 7.6(\mathrm{D})$; Long, supra note 115, at 878; Comment, Sailing the Uncharted Seas, supra note 90, at 1186-87.

117. D. DoBBS, supra note $1, \S 3.9$, at 205.

118. See Comment, supra note 47 , at $654-55$.

119. Mallor \& Roberts, supra note 45 , at 650 .

120. Comment, Sailing the Uncharted Seas, supra note 90, at 1186-87. 
mentioned above. ${ }^{121}$ For example, an award of punitive damages may be justified under this rationale where an insurer engages in a systematic policy of denying coverage to the disadvantage of its insureds. ${ }^{122}$

The private attorney general rationale is at best incoinplete, however, for it presupposes that the rationales of punishment and/or deterrence justify the civil "prosecution" of the defendant. ${ }^{123}$ The force of coinpensation as a rationale justifying the award of punitive damages in a contractual setting thus depends on the strength of the other two rationales. Moreover, if punishment or deterrence is the underlying justification, it may also be questioned whether encouraging private litigation through awards of punitive damages is the most efficient means to effect those goals.

\section{B. Punishment}

Punishment is another often cited rationale behind awards of punitive damages. ${ }^{124}$ Traditionally, punishment has been utilized to express the public's outrage towards the conduct of the defendant. ${ }^{125}$ Awards of punitive dainages in soine "bad faith" cases exhibit this element of public condemnation towards the actions of institutions that the public perceives to be, for the most part, outside the ainbit of criminal law. Punishment or retribution in this context is achieved through the inposition of monetary dainages.

Punishment is dependent on notions of public morality. Fairness requires that punishment be imposed for conduct that is definitively wrongful, and that it be applied equally to all offenders. ${ }^{126}$ Problems of fairness result when standards governing conduct are vague. Vagueness in standards for awarding punitive daniages in borderland cases is thus of particular concern to the extent that punishment serves as the underlying rationale for the imposition of punitive damages. Even putting aside sucli potential probleins, retribution or inere vindictiveness which seeks only to inflict damages ex post to right past injuries which cannot be undone is a particularly unsatisfactory rationale in the context of commercial transactions. ${ }^{127}$

121. Id. at 1189 .

122. See Chodos v. Insurance Co. of N. Am., 126 Cal. App. 3d 86, 178 Cal. Rptr. 831 (1981) (automobile insurer breached implied covenant of good faith and fair dealing by failing to reimburse insured after agreeing to allow insured to settle property damage claim when evidence showed that failure to reimburse was due to systematic policies adopted by the insurer).

123. Ellis, supra note 16 , at 10 .

124. See D. DoBBS, supra note $1, \S 3.9$, at 205; J. GHIARDI \& J. KIRCHER, supra note 45, $\S \S$ 2.02-.05, at 4-13; Ellis, supra note 16, at 4-8.

125. Long, supra note 115, at 876; Mallor \& Roberts, supra note 45, at 648.

126. Ellis, supra note 16 , at $4-8$.

127. Mallor \& Roberts, supra note 45, at 648 . By contrast, where the extent of potential liability 


\section{Deterrence}

Neither punishment nor compensation offers a complete rationale for awarding puntive damages in borderland cases. Deterrence provides the only completely satisfactory rationale for the imposition of punitive damages in these cases.

Punitive damage awards deter both parties to the action: they deter the defendant from engaging in such conduct in the future, and they deter the plaimtiff from engaging in acts of revenge. Punitive damage awards also deter other potential offenders. Deterrence is the only rationale that provides a completely satisfactory answer to the question, "Why should the defendant be punished?" 128 The answer is that deterrence brings about a positive gam to society through the reduction of future misconduct. Awards of punitive damages act to control future behavior-and thus to enforce desireable social norms-by raising the costs of such imisconduct. ${ }^{129}$ Because deterrence is the niost forceful justification for awarding punitive damages in borderland cases, the following discussion will focus on the maximization of deterrence.

According to Professor Ellis, punitive damages serve as an efficient deterrent mechanism in two situations: first, "where expected liability for compensatory damages is less than expected harm to society or [second,] where harm is dehberately caused and the satisfaction obtained by the actor is 'illicit." "130 Ellis also mentions an additional situation im which pumitive damages might produce an efficient outcome: where the ex ante probability of being held liable for the loss is less than the actual probability of the harm. ${ }^{131}$ As another commentator has noted, these three categories in which pumitive damages serve an efficient level of deterrence are so broad as to be almost all-niclusive. ${ }^{132}$ For example, the ex ante probability of being held hable will be less than the probability of harm in nearly all situations. ${ }^{133}$

Nevertheless, Ellis's generalizations have some significance for awards of punitive damages for the breach of the covenant of good faith

can be ascertained in advance and where damages are proportionate to the harm inficted and applied uniformly, the imposition of liability directly serves the goal of deterrence.

128. See Ellis, supra note 16, at 8; Morris, Punitive Damages in Tort Cases, 44 HARv. L. Rev. 1173,1174 \& n.1 (1931).

129. Mallor \& Roberts, supra note 45 , at 648 .

130. Ellis, supra note 16 , at 77.

131. Id. at 25.

132. Owen, Civil Punishment and the Public Good, 56 S. CAL. L. Rev. 103, 112-14 (1982).

133. Id. at 113. Owen concludes from the comprehensiveness of the categories that "if the normal rules of good behavior are themselves defined in terms of cost efficiency, and if the threat of punitive damages will steer persons towards compliance with the rule, then a 'proper' amount of punitive damages should be efficient as a general proposition rather than in only limited situations." Id. at 114. Owen then focuses on the formulation of legal rules to further fairness and efficiency in the area of punitive damages. 
and fair dealing. In some cases, breaches of the implied covenant display the characteristics of harm dehiberately caused and illicit satisfaction obtained by the breaching party. In other cases, the breaching party may calculate his expected liability for compensatory damages for breach of the covenant of good faith and fair dealing at a level that is less than the actual harm to society caused by his breach. This result may occur because the imjurer does not expect to pay the full price of his actionsthere may be costs to both the plaintiff and society that remain uncompensated. Alternatively, this result may occur when the breaching party engages in a systematic practice of inflicting harm that, although significant in the aggregate, is too slight in the individual case for the injured party to brimg suit. In this latter group of cases, the ex ante probability of being held hable may be small, although the probability that harm will result from such a systematic policy may be high. In these cases, punitive dainages can alter the breacher's calculations and promote deterrence. Thus, deterrence is a particularly convincing rationale for awards of purntive damages aimed at correcting repeated institutional conduct which fails to take the rights of individuals into account.

III

APPLYING STANDARDS FOR AWARDING Punitive Damages

As the previous Part has shown, only deterrence offers a completely satisfactory rationale for awards of punitive damages in borderland cases. The goal $\mathrm{m}$ formulating standards for such awards therefore should be to maximize the deterrent function. Current standards, however, offer only a confusing and inadequate solution. In formulating new standards that maximize deterrence, courts should tailor standards to fit categories of cases and categories of defendants. In particular, in the borderland of contract and tort, an objective standard (such as "oppression") is preferable to a subjective one (such as "malice") because the objective standard better effectuates deterrence. This Part will discuss both the problem with the existing state of the law and the formulation of new standards.

\section{A. The Problem of Vague Standards}

Vagueness in the standards for awarding punitive damages is an especially serious concern in actions arising out of the borderland of contract and tort for two reasons. First, vagueness decreases the fairness and deterrent values of punitive damages, thus raising the social costs for their imposition, ${ }^{134}$ perhaps enough to counsel the denial of such awards in borderland cases. Vagueness decreases fairness by failing to specify

134. Id. 
behavior subject to civil penalty; ${ }^{135}$ it also decreases deterrence due to the uncertainty interjected into the breaching party's calculation of his costs. ${ }^{136}$ Second, standards for awards of punitive damages are inherently difficult to elucidate in actions in the borderland, such as a breach of the implied covenant of good faith and fair dealing. The cases distinguish "bad faith," which justifies the imposition of compensatory tort damages, from "inalice," "fraud," and "oppression," which justify the imposition of pumitive dainages. ${ }^{137}$ In such cases, the distinction between "bad faith" and "mahice" is more theoretical than functional and is frequently misapplied by courts and misunderstood by commentators. ${ }^{138}$

Various standards have been einployed to justify the imposition of punitive damages. For example, the California Civil Code allows the plaintiff to collect pumitive damages when she can show that the defendant's conduct has exhibited the requisite "inalice," "oppression," or "fraud." 139 Section 3294 of the Civil Code defines these ternis as follows:

(1) "Malice" ineans conduct which is intended by the defendant to cause injury to the plaintiff or conduct which is carried on by the defendant with a conscious disregard of the rights or safety of others.

(2) "Oppression" means subjecting a person to cruel and unjust hardship in conscious disregard of that person's rights.

(3) "Fraud" ineans an intentional misrepresentation, deceit, or concealment of a material fact known to the defendant with the intention on the part of the defendant of thereby depriving a person of property or legal rights or otherwise causing injury. ${ }^{140}$

Even given these defintions, however, the requisite state of mind is by no means clear. For exainple, the standard of "inalice" as defined in section 3294 has been subject to differing statutory and case law interpretations. While an amendment to section 3294 in 1980 expanded the definition of "malice," theretofore defined as actual inalice, to include acts carried on in conscious disregard of another's rights, the amendment failed to define the level of culpability necessary to support a finding of "conscious disregard." 141 Furthermore, while the amendment listed the two standards in the alternative through the use of the disjunctive "or", prior case law posited the two standards conjunctively: actual malice and conscious disregard. ${ }^{142}$ The difference between these two interpretations is potentially

135. Id. at 114-15.

136. Ellis, supra note 16 , at 39-40.

137. See infra text accompanying notes 143-54.

138. Ellis, supra note 16 , at $34-37$.

139. Cal. Civ. Code $\S 3294$ (West Supp. 1985).

140. Id.

141. Comment, supra note 16 , at 1066.

142. Egan v. Mutual of Omaha Ins. Co., 24 Cal. 3d 809, 822, 620 P.2d 141, 147, 169 Cal. Rptr. 691, 697 (1979), appeal dismissed and cert. denied, 445 U.S. 912 (1980); Neal v. Farmers Ins. Exch., 21 Cal. 3d 910, 923, 582 P.2d 980, 986-87, 148 Cal. Rptr. 389, 395-96 (1978). 
significant, as conscious disregard appears to denote a lower level of culpability than actual malice.

Indeed, the case law in general manifests a lack of precision concerning exactly what standards the courts are employing. In Neal $v$. Farmers Insurance Exchange, ${ }^{143}$ a case involving an insurer's breach of the implied covenant of good faith and fair dealing, the California Supreme Court sustained an award of punitive damages, stating that there was substantial evidence that the defendant had "acted maliciously, with an intent to oppress, and in conscious disregard of the rights of its insured."144 Yet the Court went on to admit that "[i]t is true that the record contains no direct evidence that defendant, in pursuing the course of conduct that it did, acted with the indicated motivation and intent." 145 The Court then reasoned that the requisite state of mind could be proven implicitly, by indirect evidence from which the jury may draw inferences. ${ }^{146}$ This combination of various standards does little to elucidate the culpable state of mind required of the defendant. This lack of precision reduces the deterrent effect of punitive damage awards.

In Silberg v. California Life Insurance Co., ${ }^{147}$ an earlier case involving an insurer's tortious breach of the implied covenant, the court pointed out that a violation of the duty of good faith and fair dealing alone "does not necessarily establish that the defendant acted with the requisite intent to mjure plaintiff." 148 Yet the court repeated the same litany of standards-oppression, fraud, and malice-without explaining the relevance of the standards to the case at hand. ${ }^{149}$ In affirming an order granting a new trial, the court appeared to adopt the oppression standard when it stated, "The trial court's conclusion that defendant was not guilty of oppressive conduct did not constitute . . . [an] abuse of discretion." 150 However, because the court seemed to consider other factors as well, the precise standard the court intended to articulate remained unclear.

To confound matters even further, in Egan v. Mutual of Omaha Insurance Co., ${ }^{151}$ the court seemed to forget its earlier distinction between '[ $t$ ]he terms of 'good faith' and 'bad faith,'.. . [which] are not meant to connote the absence or presence of positive misconduct of a

143. 21 Cal. 3d 910, 582 P.2d 980, 148 Cal. Rptr. 389 (1978).

144. Id. at 923,582 P.2d at 986-87, 148 Cal. Rptr. 395-96.

145. Id. at 923 n.6, 582 P.2d at 987 n.6, 148 Cal. Rptr. at 396 n.6.

146. Id. (citing Davis v. Hearst, 160 Cal. 143, 162, 116 P. 530 (1911), and Bertero v. National Gen. Corp., 13 Cal. 3d 43, 66, 529 P.2d 608, 625, 118 Cal. Rptr. 184, 201 (1974)).

147. 11 Cal. 3d 452, 521 P.2d 1103, 113 Cal. Rptr. 711 (1974).

148. Id. at $463,521 \mathrm{P} .2 \mathrm{~d}$ at 1110,113 Cal. Rptr. at 718.

149. Id. at 462,521 P.2d at 1110,113 Cal. Rptr. at 718 .

150. Id. at $463,521 \mathrm{P} .2 \mathrm{~d}$ at 1110,113 Cal. Rptr. at 718.

151. 24 Cal. 3d 809, 620 P.2d 141, 169 Cal. Rptr. 691 (1979), appeal dismissed and cert. denied, 445 U.S. 912 (1980). 
malicious or immoral nature-considerations which ... are more properly concerned in the determination of liability for punitive damages."152 In Egan, the court suggested that the very nature of a breach of the duty of good faith and fair dealing justified the imposition of punitive damages. The court reasoned that awards of punitive damages in such cases serve as a recognition of the "special relationship" between the insurer and insured and reflect an attempt to balance the contractual positions of the parties. It is unclear, however, whether the case actually formulated a new standard or merely approved of awards of punitive damages "in cases in which the statutory prerequisites are fulfilled." 153 In fact, the court later concluded that there was sufficient evidence of "malice," quoting the standard laid down in Neal with approval. ${ }^{154}$

\section{B. The Need for an Objective Standard}

As this brief excursion has shown, the courts have yet to formulate a set of distinct standards for the imposition of punitive dainages. A new approach to the problem is needed. Professors Ellis and Owen have made a beginning in their suggestion that we "need to specify inore carefully the categories of inisconduct for which purntive damages are in order ...."15s Owen has taken this idea a step further by specifying three classifications-types of defendants, states of nind, and the nature of misdeeds-that could form the basis of such categories. ${ }^{156}$ The specific nature of the punishable conduct would thus dictate the applicable standard for the imposition of punitive damages.

For exainple, an insurer's breach of the imphed covenant of good faith and fair dealing could be analyzed utilizing this threefold classification. First, it is necessary to determine the type of defendant most coinnonly implicated. In this case, virtually all insurers are corporations. While the liability of corporations for punitive damages under agency law poses problenis beyond the scope of this Coninent, California courts have chosen to impose such hability on corporations when their einployees possess the degree of discretion in making decisions that will "ultimately determine corporate policy." 157 In Merlo v. Standard Life \& Accident Insurance Co., ${ }^{158}$ Judge Tamura reasoned, "It inust be remeinbered that we are here concerned with an insurance coinpany dealing in disability insurance. ... Manifestly, to plaintiff, [the claim

152. Neal, 21 Cal. 3d at 921 n.5, 582 P.2d at 986 n.5, 148 Cal. Rptr. at $395 \mathrm{n} .5$ (emphasis in original).

153. Egan, 24 Cal. 3d at 820, 620 P.2d at 146, 169 Cal. Rptr. at 696.

154. Id. at 822,620 P.2d at 147,169 Cal. Rptr. at 697.

155. Ellis, supra note 16, at 39-53; Owen, supra note 132, at 116.

156. Id. at 105-09.

157. Egan, 24 Cal. 3d at 823, 620 P.2d at 148, 169 Cal. Rptr. at 698.

158. 59 Cal. App. 3d 5, 130 Cal. Rptr. 416 (1976). 
representative's] actions were actions of the defendant. . . . Defendant should not be allowed to insulate itself from liability by giving an employee a nonmanagerial title and relegating to hin crucial policy decisions." 159 Thus, it is necessary to fashion a standard for the imposition of pumitive damages that takes corporate structure into account.

In addition to the defendant's likely status as a corporation, the institutional power that this type of corporation holds over the individual is important. The extent to which the defendant is able to dictate the terms of the contract is relevant, as is the extent to which the plaintiff places his trust in the defendant. Public expectations concerning the use of bargaining power are dependent upon the extent to which a party enters into a contract with the defendant to secure an essential service or product, financial security, or peace of inind.

The defendant's state of inind is the second crucial eleinent in formulating standards for awarding puritive dainages. According to Owen, there are essentially three inental states that support punitive awards to varying degrees: dehiberate, evaluative, and inadvertent. ${ }^{160}$ The acts of an institutional defendant such as an insurance company inay fall into any of the three categories. An insurer may be said to be acting "deliberately" or "mahiciously," when there is no vahid business reason for its conduct. In a few isolated instances, an insurer may act "maliciously" when its employees engage in tortious activity for reasons of spite or ill will. An insurer may act "evaluatively" when it knows the probable results of its actions, but for business reasons engages in such action anyway. Here, the insurer has often made a cost-benefit analysis and from that has adopted a "company" rule or course of action. Finally, an insurer may act "inadvertently" when it neglects or consciously avoids knowledge of the consequences of its actions.

Varying levels of culpability attach to the three inental states. An insurer which acts deliberately is obviously the most culpable, and awards of punitive damages are certainly appropriate in such cases. However, instances of such dehberate action are uncoinmon and proof of such instances is even more uncommon. Rather, an institutional defendant is more likely to engage in conduct that is evaluative or inadvertent. In such cases, an award of punitive dainages inay be equally appropriate when the institution has made a decision that fails to coinport with the expectations of the public regarding a quasi-public fiduciary. This is especially true if the institution's decision is one that is likely to affect many individuals, as when the institution has adopted a policy which systematically fails to take the rights of these individuals into account.

159. 59 Cal. App. 3d at 25, 130 Cal. Rptr. at 429 (Tamura, J., concurring and dissenting) (cited with approval in Egan, $24 \mathrm{Cal}$. 3d at 823, 620 P.2d at 148, 169 Cal. Rptr. at 698).

160. Owen, supra note 132 , at 106. 
As a final classification, Owen suggests that we look at the nature of the inisdeeds, focusing on the distinction between misfeasance and nonfeasance advocated by Dean Prosser. ${ }^{161}$ Thus, affirmative conduct on behalf of the insurer to deny the plaintiff the benefits of a policy may be relevant. Nevertheless, although the active/passive distinction between misfeasance and nonfeasance may be helpful in some cases, its importance should not be overestimated. At common law, liability for exemplary damages im public callings extended both to the refusal to serve and to the provision of service that did not meet inimimal expectations. Thus, an institutional defendant imight be held liable even for nonfeasance. Other factors sliould be considered here as well, such as whether the nature of the injury is such that ordimary contract damages do not make the plaintiff whole and do not require the defendant to account for his actions.

In sum, we must formulate standards for pumtive damages that are tailored to categories of beliavior and to categories of defendants. As Owen points out, "The word 'malicious,' for example, is virtually meaningless as applied to passive, institutional failures to consider the implications of their activities, yet the word applies quite well to an individual defendant who deliberately and by affirmative action inflicts harm upon another for no good reason."162

In borderland cases, the problem can be expressed as the need for an objective rather than a subjective standard. Standards such as "malice" fail to convey the rationale belind the award of exemplary damages, where deterrence is the main concern. Since the primary purpose of pumitive damage awards is deterrence, subjective standards such as "malice" are inappropriate in cases involving institutional defendants. Deterrence is not sufficiently fostered in this context by the use of a subjective standard, such as malice, which focuses upon the "evil intent" of the defendant. A plaintiff will rarely be able to offer proof of malice in an institutional context. More importantly, such a standard fails to focus upon the aspect of the institutional defendant's conduct tliat punitive damages seek to deter.

An objective standard, such as "oppression," which focuses on the actual abuse of bargaming power by the defendant, is preferable in this category of cases. Such a standard puts the defendant on notice, giving him a more definite standard by wlich to judge his conduct. It thus better serves the goal of deterrence.

Although Elhs recognizes the need to formulate new standards, he rejects substituting other terms, such as "outrageous" or "flagrant," for

161. Id. at 108; see W. Prosser, supra note 2, at 338.

162. Owen, supra note 132 , at 116. 
"the plethora of vague and overlapping terms currently used."163 Owen, on the other hand, suggests phrases such as "'flagrant disregard' of the plaintiff's rights and 'extreme departure' from the relevant norm."164 While Owen's suggestions are helpful, they need to be articulated with the precision that can only come through case law development. Meanwhile, the "oppression" standard offers a useful, objective means of evaluatimg the defendant's conduct by shifting the focus of the court's concern from the defendant's bad faith to the extent to which the defendant's conduct oppressed the plaintiff.

\section{CONCLUSION}

In the case of a breach of the covenant of good faith and fair dealing, we are primarily concerned with the institutional failure to take account of the rights of individuals in the corporate decisionmaking process. It is the ability of these institutions wittingly or unwittingly to oppress the plaintiff by this omission that is the relevant factor for awarding punitive damages. Therefore, this Comment proposes that the standard for punitive damages be built around the concept of oppression. While this standard would go a long way toward increasing the efficiency and fairness of awards of exemplary damages, it should be accompanied by other procedural changes, such as puttimg limits on the discretion of the jury, in order to provide a complete system of deterrence. Such changes should be tailored-like the proposed change of substantive standards-to provide an objective standard against which a defendant's conduct can be judged.

Leslie E. John*

163. Ellis, supra note 16 , at 51 .

164. Owen, supra note 132 , at 115.

* A.B. 1984, University of California, Berkeley; third-year student, Boalt Hall School of Law, University of California, Berkeley. 